\title{
Preparation and Characterization on Natural Dyes Based on Neem, Henna and Turmeric for Dyeing on Cotton with Superhydrophobic Coating
}

\author{
Rupashinii Thana Singam ${ }^{1}$, Noraini Marsi ${ }^{1 *}$, Hasri Mamat ${ }^{2}$, Anika Zafiah Mohd \\ Rus $^{3}$, Nor Mazlana Main ${ }^{1}$, Siti Aida Ibrahim ${ }^{1}$, Nur Athirah Huzaisham ${ }^{1}$ and \\ Muhammad Haikal Mohd Fodzi ${ }^{1}$
}

${ }^{1}$ Innovative Manufacturing Technology (IMT), Universiti Tun Hussein Onn Malaysia (UTHM), Hub Pendidikan Pagoh, KM 1, Jalan Panchor, Pagoh, 86400, MALAYSIA

${ }^{2}$ Puspamara Sendirian Berhad (A member of NADICORP Holdings Sdn. Bhd.), Batu 1ํㅡ, Jalan Sungai Chua, P.O Box 3, 43007 Kajang, Selangor, MALAYSIA

\begin{abstract}
${ }^{3}$ Sustainable Polymer Engineering, Advanced Manufacturing and Materials Center (SPEN- AMMC), Universiti Tun Hussein Onn Malaysia (UTHM), Hub Pendidikan Pagoh, KM 1, Jalan Panchor, Pagoh, 86400, MALAYSIA

*Corresponding Author

DOI: https://doi.org/10.30880/ijie.2019.11.07.018

Received 09 October 2019; Accepted 25 October 2019; Available online 15 November 2019

Abstract: This study is presents the preparation and characterization on natural dyes based on neem, henna and turmeric for dyeing on cotton with superhydrophobic coating. Natural dyes were used to reduce the usage of the synthetic dyes in dyeing process and superhydrophobic coating to maintain the colour of the dyes on the fabric from faded and acts as a self-cleaning. The methodology involved for this study was the extraction process of natural dyes from the neem, henna and turmeric. There are eight different concentrations consists of $0.25 \mathrm{~g} / \mathrm{ml}$, $0.5 \mathrm{~g} / \mathrm{ml}, 0.75 \mathrm{~g} / \mathrm{ml}, 1.0 \mathrm{~g} / \mathrm{ml}, 1.25 \mathrm{~g} / \mathrm{ml}, 1.50 \mathrm{~g} / \mathrm{ml}, 1.75 \mathrm{~g} / \mathrm{ml}$ and $2.0 \mathrm{~g} / \mathrm{ml}$. The mechanical test involved is abrasion test for evaluation the resists wear caused by flat rubbing contact with another materials. Henna coated cotton fabrics have lower percentage weight loss compared to neem and turmeric coated cotton fabrics and uncoated cotton fabrics. The weight percentage loss for henna coated cotton fabrics at $2.0 \mathrm{~g} / \mathrm{ml}$ was $3.32 \%$, for neem coated cotton fabrics at $2.0 \mathrm{~g} / \mathrm{ml}$ was $3.33 \%$ and turmeric at $2.0 \mathrm{~g} / \mathrm{ml}$ concentration was $3.34 \%$. On the other hand, the value for the henna uncoated cotton fabric at $2.0 \mathrm{~g} / \mathrm{ml}$ was at $3.41 \%$, neem at $2.0 \mathrm{~g} / \mathrm{ml}$ concentration was $3.42 \%$ and the value for uncoated turmeric at $2.0 \mathrm{~g} / \mathrm{ml}$ was $3.43 \%$ respectively. The porosity decreases when the concentration of dyes and superhydrophobic coating applied on the cotton fabrics.
\end{abstract}

Keywords: Natural dyes, superhydrophobic coating, extraction, fabrics.

\section{Introduction}

Textile materials are mainly from synthetic dyes where it was produced from petrochemical which are not renewable and not biodegradable [1]. Around 30 million tonnes of dye was estimated for the global consumption for textiles and was expected to grow up to $3 \%$ per annum while 70,000 tonnes of dyes were released to the environment [2]. The population of people who will have allergic to the chemicals will grow up to 60 per cent by year 2020 which was stated in a business week [3,4]. In addition, approximately 280,000 tons of textile dyes are discharged annually worldwide and approximately 10,000 different dyes have been produced and an estimated $8 \times 10^{5}$ tons of synthetic dyes 
are used in the textile industry worldwide [4,5]. Natural dyes become an alternative way to the industries when synthetic dyes caused severe problems such as visible residues in the effluent [5] and toxic amines were created [6]. On the other hand, natural dyes can return to nature at the end of use, such as wastewater from dyeing process. Therefore, researchers are interested in natural dyes because it is more compatible with the environment and has an antibacterial and ultraviolet protection functions [6,7]. Synthetic dye production involves a large number of cancer-causing synthetic chemicals and effluents that are released into the water or produced into the air resulting in contamination. Besides that, interest in the usage of natural dyes has been revived worldwide due to the toxic nature and effect of synthetic dyes on all forms of life. There are many examples of natural dyes such as henna which was used in textile fabrics [7] and it contains red-orange pigment known as 2-hydroxyl-1, 4-napthaquinone [8]. Henna leaves have many names, such as hina, henna tree, mignonette tree, and Lawsonia Inermis, scientifically derived from Egyptian privet [9]. Furthermore turmeric was used for medicinal properties and curcumin is the colouring agent which produce yellow colour [10]. The scientific name for turmeric is called the rhizome Curcuma longa and the family name is Zingiberceae [11]. Turmeric dyed cotton fabric has an excellent UV protection properties and good home laundering longevity. Moreover neem is a renewable source for soap industry, medicines and textile industry where azadirachtin produce green colour [12,13]. The scientific name for neem plant is Azadiractha Indica, a plant belonging to the Mahogany family known as Meliaceae [14].

Cotton fabrics have cellulose and abundant hydroxyl groups structure where it will make hydrophilic properties where the fiber can provide an appropriate environment for microorganism growth when in contact with water and sweats . Besides that, cellulose as $94 \%, 1.3 \%$ protein, $0.9 \%$ pectin, $1.2 \%$ oil, $0.6 \%$ wax and $2 \%$ other substances are the general composition of cotton fibers. Cotton fabric is widely used in various application due to their biodegradability, renewability and environmental friendly where it does not contain any harmful composition [15]. On the other hand, superhydrophobic coating acts as self-cleaning and protection to the products . Coating technology has desirable performance such as mechanical properties, water resistance, antibacterial properties, UV resistance and can be used in food, clothing, paper packaging and other applications. Hydrophobic materials have been incorporated into the fabric layer with paraffin waxes and paraffin emulsion, resulting in inadequate air and vapor permeability and poor comfort. Nano-scaled particles such as silicon dioxide $\left(\mathrm{SiO}_{2}\right)$, titanium dioxide $\left(\mathrm{TiO}_{2}\right)$ and zinc oxide $(\mathrm{ZnO})$ were then used to coat and improve the textile fiber surface roughness [16]. In this research natural resources such as neem, henna and turmeric have been used to replace the artificial dye where synthetic dye can lead to severe contamination of wastewater and human health effects. On the other hand, the superhydrophobic coating was used in this research to enhance the mechanical properties for the fabric where superhydrophobic coating was synthetize from the titanium dioxide. The main objectives of this research is to evaluate the abrasion strength and porosity for the uncoated and coated dyed cotton fabrics.

\section{Materials and method}

The materials were natural resources based on neem, henna and turmeric to dye on cotton fabric for dyeing. Henna is known as Lawsonia Inermis which belong to the Lythraceae's family and produce orange-red colour. Apart from that, neem plant was known as Azadiractha Indica was from Mahogany family known as Meliceae. Turmeric also known as Curcuma Longa from rhizome and Zingiberceae is the family name for the turmeric plant. The neem, henna and turmeric were cut from plant and washed thoroughly with water for five times [17]. Then the neem, henna and turmeric were dried in the oven for $57^{\circ} \mathrm{C}$ for 24 hours. After that, the dried leaves were grind by using grinder into powdered form for effective extraction. The particle size for the powdered form was $0.05 \mu \mathrm{m} \pm 0.01$. Then the powdered samples were sieved with a sieve size 0.05 um with 270 meshes to remove some stalk that is not well ground [18]. The methods used in extracting dye for neem, henna and turmeric were cold water extraction. Later the powdered dyes were weighed into $10 \mathrm{~g}, 20 \mathrm{~g}, 30 \mathrm{~g}, 40 \mathrm{~g}, 50 \mathrm{~g}, 60 \mathrm{~g}, 70 \mathrm{~g}$ and $80 \mathrm{~g}$. Then $40 \mathrm{ml}$ of distilled water were added into the divided powdered dyes respectively. Moreover the water based dye were filtered using filter paper Whitman No $1,6 \pm 1 \mu \mathrm{m}$. Table 1 shows the concentration of dyes.

Table 1 - Concentration of dyes

\begin{tabular}{ccc}
\hline Powdered dye (g) & Distilled water $(\mathbf{m l})$ & Concentration of dye $(\mathbf{g} / \mathbf{m l})$ \\
\hline 1 & 4 & 0. \\
2 & 4 & 0. \\
3 & 4 & 0. \\
4 & 4 & 1. \\
5 & 4 & 1. \\
6 & 4 & 1. \\
7 & 4 & 1. \\
80 & 40 & 2.00 \\
\hline
\end{tabular}




\subsection{Process of superhydrophobic coating}

The superhydrophobic coating has three stages which are alcoholysis, condensation and purification. For stage alcoholysis the $50.3 \%$ of solvent which is fluorocarbon was used and mixed with $80 \mathrm{ml}$ of crosslinker isopropyl alcohol. Then second stage was condensation step which $2.4 \%$ (wt/wt $\%$ ) was used to produce the binder. Third step is purification step. The solution that was produced from first stage and second stage were undergoing mixing and stirring process for 45 minutes at $70^{\circ} \mathrm{C}$. Then the DI water was doped with $\mathrm{TiO}_{2}$ powder. The solutions will heat at 1000 for 60 minutes. Lastly the superhydrophobic coating will pour into the spray and gun and spray on the dyed cotton fabrics [19]. The method of coating was spraying technique. The standard environment for drying time of air dry was $23 \pm 20 \mathrm{C}$ while the relative humidity was $50 \pm 5 \%$ under diffuse sunlight. The angle for spray gun and the coated fabric was 450 by swing the gun back and forth across the surface. The coating layer for each concentration dyed cotton fabrics were five layers.

\subsection{Abrasion test (ASTM 4966-98)}

Abrasion test was conducted to test the ability to resist wear caused by flat rubbing contact with another material. Abrasion test was inspected for wear and tear resistance of the fabrics. The ASTM 4966-98: Standard Test Method for Abrasion Resistance for Textile Fabric (Martindale Abrasion Tester Method). Figure 1 show the schematic diagram of abrasion test where the abrasion machine was pulled out the fabrics and loaded with the weight [20].

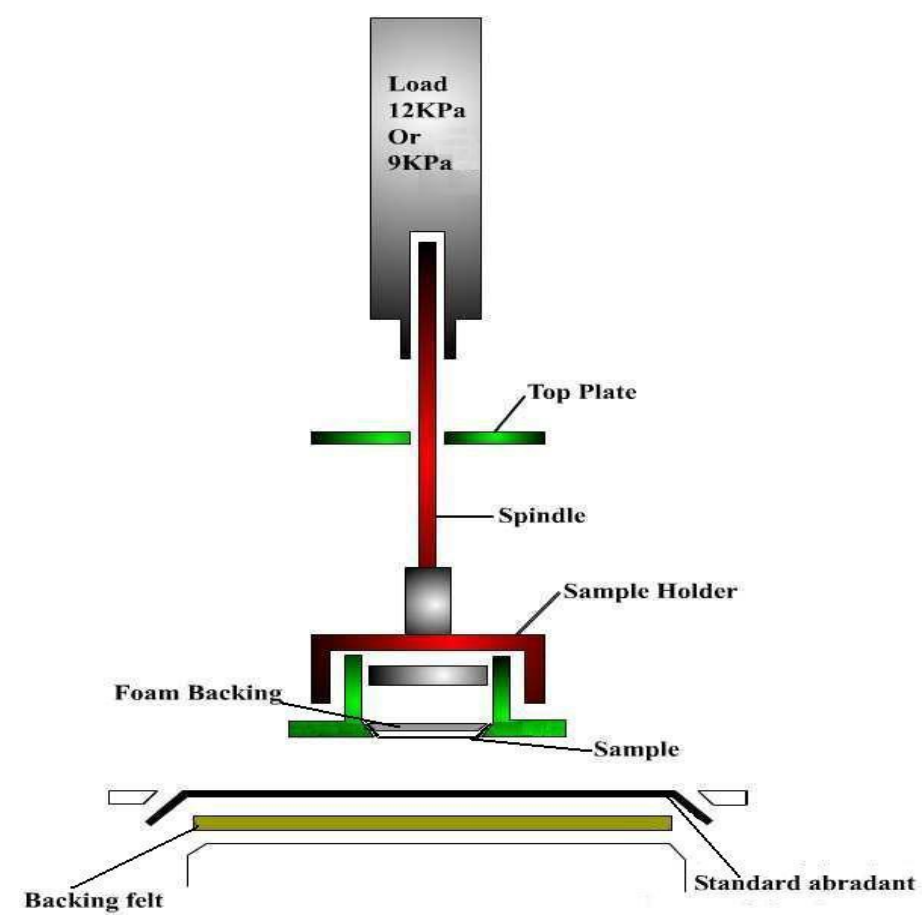

Fig. 1- Schematic diagram of abrasion tester [20]

Martindale abrasion tester was used for this study. The test procedure is four pieces of abrasive material s were cut into $140 \mathrm{~mm}$ diameter. Then, the fabrics sample with coated and uncoated dyed cotton fabrics were cut into $38 \mathrm{~mm}$ diameter. All the dyed cotton fabrics and uncoated dyed fabrics for three types were weighed and the $12 \mathrm{~kg}$ of load was put on the samples. The rubbing cycle was 5000 times and the weight of the fabric before and after was weighed [21]. The percentage of weight loss was calculated.

\subsection{Porosity test (ASTM A276)}

The porosity test was conducted using Olympus Metallographic Microscope and Image Analysis Software. Moreover the standard method was Standard Test Method for Porosity on Textile Fabric (Metallographic Image Analysis). The fabric size was $5 \mathrm{~cm}$ x $5 \mathrm{~cm}$ according to the standard method. Eight different concentrations based on neem, henna and turmeric fabrics with coated and uncoated were used for this test. Olympus microscope was the tool for measuring the area fraction and number of pores on cross-sectional surfaces and coating fabrics. Apart from that, the software was used threshold method to differentiate between the pores and the substrate on colour. Then the pore 
density and the size of the largest pore were calculated for every selected region of interest on the whole image. Besides that, the magnification lens was $\mathrm{x} 5$.

\section{Results and Discusion}

\subsection{Abrasion test}

From figure 2 the percentage of weight loss for the coated dyed fabrics are lower than the uncoated dyed cotton fabrics. The percentage of weight loss for the 1000 rub cycles coated henna dyed cotton fabrics are lower compared to the neem and turmeric. The weight loss for the coated henna dyed cotton fabrics are from $3.32 \%$ to $3.38 \%$ from $0.25 \mathrm{~g} / \mathrm{ml}$ to $2.0 \mathrm{~g} / \mathrm{ml}$ concentrations. The weight loss for the coated neem dyed cotton fabrics are from $3.33 \%$ to $3.39 \%$ for the concentration $0.25 \mathrm{~g} / \mathrm{ml}$ to $2 \mathrm{~g} / \mathrm{ml}$ and coated turmeric dyed cotton fabrics have $3.34 \%$ to $3.40 \%$ respectively. On the other hand, the weight loss for the concentration $0.25 \mathrm{~g} / \mathrm{ml}$ to $2 \mathrm{~g} / \mathrm{ml}$ for the uncoated henna was $3.48 \%$ to $3.41 \%$, uncoated neem was $3.49 \%$ to $3.42 \%$ and uncoated turmeric was $3.5 \%$ to $3.43 \%$ respectively.

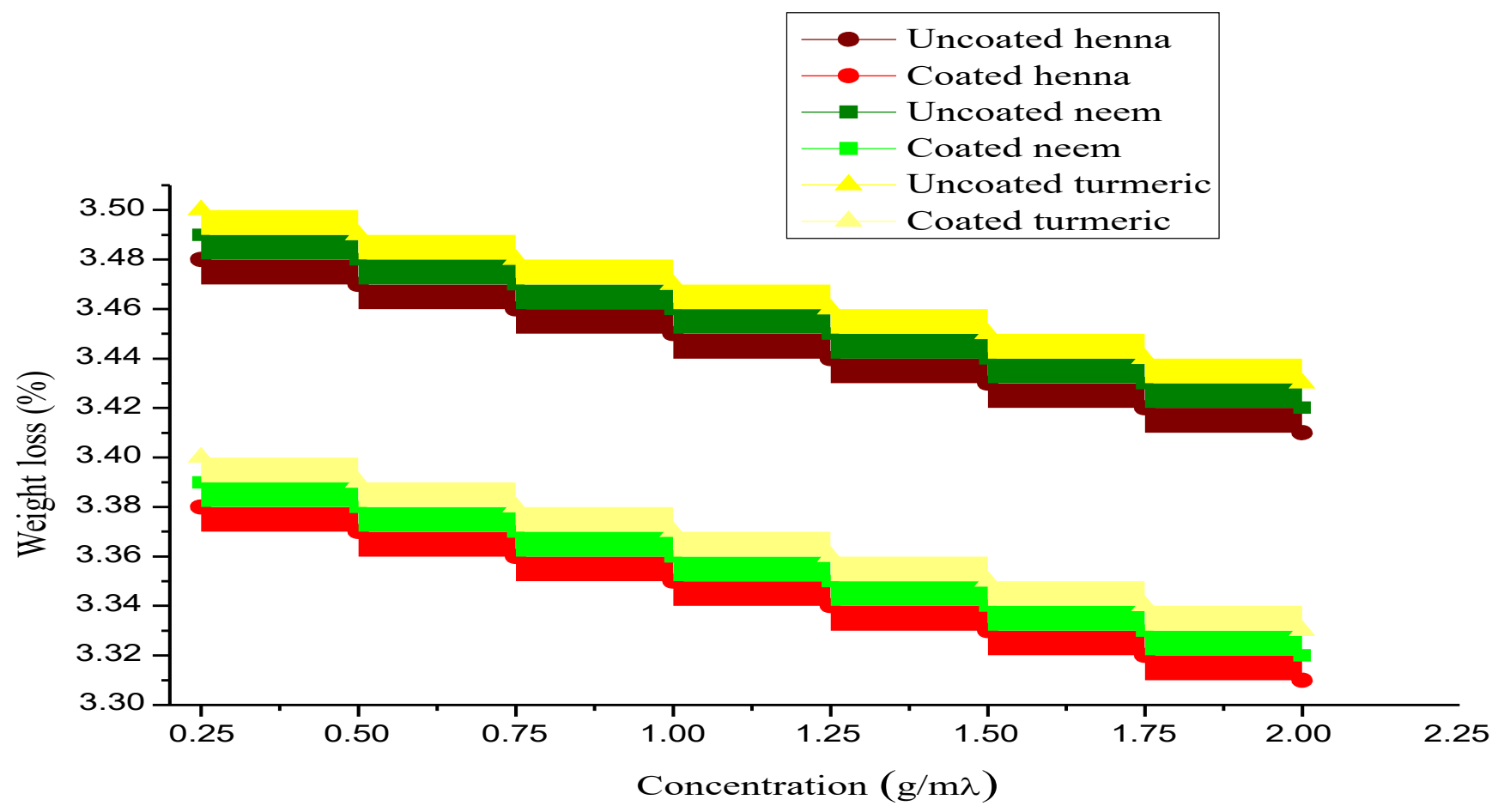

Fig. 2 - Weight loss $(\%)$ versus concentration $(\mathrm{g} / \mathrm{ml})$

There are differences in weight loss for the coated and uncoated dyed cotton fabrics. The differences between the coated and uncoated value for $0.25 \mathrm{~g} / \mathrm{ml}$ for the henna was $0.1 \%$, for neem was $0.1 \%$ and for henna as $0.1 \%$. The higher the concentration the lower the weight losses for the abrasion test. This is due to the strong covalent bond that forms between the hydroxyl group in henna structure and coating particles in the fabrics [22]. These covalent bonds enhance the strength of fibers in the fabrics [23]. Apart from that henna dye have higher affinity towards cotton fabrics because it has hydroxyl group and bonded by covalent bond [24]. Moreover the abrasion results was good for henna coated fabrics due to happens of Lawsone which are functional groups of henna dye. This Lawsone functional group is capable in forming covalent bonds with active site in the fiber such as hydroxyl group in the cotton and the bond formation was bonded between the functional groups and the substrate results in high abrasion strength and other as moderate [25]. The neem dye can form intermolecular attraction between the hydrogen structure and hydroxyl bond in the coating particles and it has slightly low abrasion value as compared to the henna dye [26]. Neem and turmeric dyed fabrics have weak energy of adsorption between surface dispersant and abrasive causes more fibers to be thorn during the abrasion process on the other material surfaces. Therefore free hydroxyl groups in the neem and turmeric may promote at a high concentration where it decrease the covelant bond between the coating particles and fibers. Due to the increase, residual abrasive particles are significantly reduced for the neem and turmeric coated fabrics. During the dyeing cycle, temperature may reduce the effect on the dye penetration process into the cotton fibers. Apart from that, it can be concluded that fabrics with superhydrophobic coating have slightly effect on abrasion resistance properties as compared to the uncoated fabrics. This is due to the particles in the coating will penetrate inside the fibers and it will form a stronger layer on the top of fabrics [27]. The weight loss of fabric is affected the superhydrophobic coating layer 
on the fabric, the rubbing action tends to damage the layer of the fabrics first then only the dyed surface [28]. Each type of natural based on neem, henna and turmeric can used for different types of application even though it gives different abrasion values.

\subsection{Porosity test}

Figure 3 shows the results that were obtained from Olympus microscope for the porosity of uncoated dyed cotton and coated dyed cotton fabrics for eight different concentrations for three types of dyes which were neem, henna and turmeric. Turmeric dyed uncoated cotton fabrics showed the porosity percentage for $0.25 \mathrm{~g} / \mathrm{ml} \mathrm{was} 11.33 \%$ and $2.0 \mathrm{~g} / \mathrm{ml}$ for $10.47 \%$ whereas for the coated dyed fabrics shown $9.98 \%$ for $0.25 \mathrm{~g} / \mathrm{ml}$ and $6.13 \%$ for $2.0 \mathrm{~g} / \mathrm{ml}$ respectively. The porosity value for the henna uncoated dyed cotton fabrics were $18.34 \%$ for $0.25 \mathrm{~g} / \mathrm{ml}$ and $10.55 \%$ for $2.0 \mathrm{~g} / \mathrm{ml}$ whereas for henna coated dyed cotton fabrics were $9.46 \%$ for $0.25 \mathrm{~g} / \mathrm{ml}$ and $6.31 \%$ for $2.0 \mathrm{~g} / \mathrm{ml}$ respectively. Besides that, neem uncoated dyed cotton fabrics were shown results as $16.45 \%$ for $0.25 \mathrm{~g} / \mathrm{ml}$ and $12.67 \%$ for $2.0 \mathrm{~g} / \mathrm{ml}$ while for the coated cotton fabrics were $11.93 \%$ for $0.25 \mathrm{~g} / \mathrm{ml}$, and $10.01 \%$ for $2.0 \mathrm{~g} / \mathrm{ml}$ respectively.

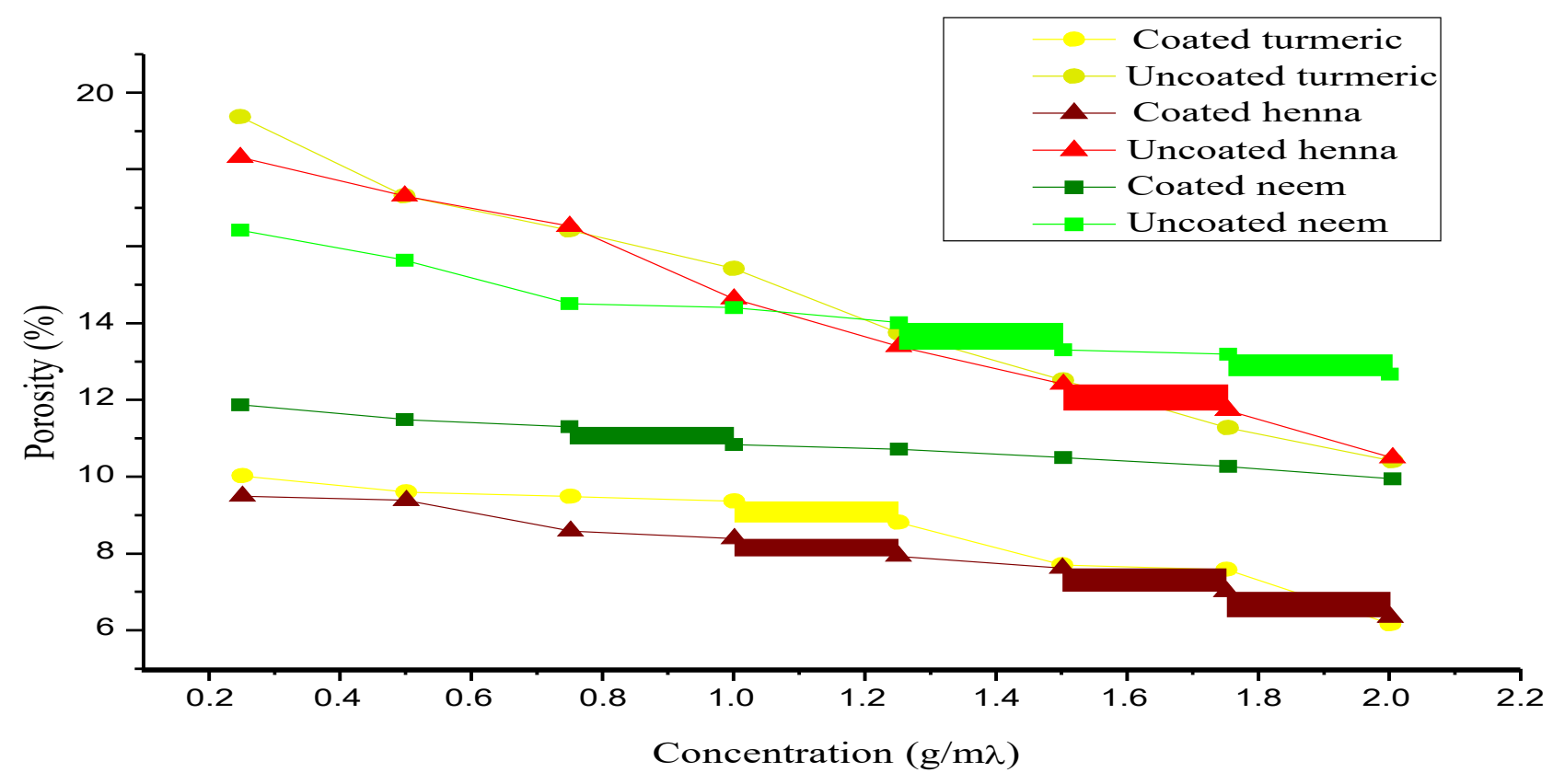

Fig. 3 - Porosity (\%) versus concentration $(\mathrm{g} / \mathrm{ml})$

The porosity value was decreased as the concentration increases with superhydrophobic coating. The porosity for the uncoated dyed cotton fabrics was higher than coated dyed cotton fabrics. This is because the particles in the superhydrophobic coating were fully covered all the pores in the fabrics and the structure of the fabrics was compact [29]. Moreover increasing amount of dyes during the dyeing process will resulted in higher rate of dye adsorption. It will increase the surface area and decrease the porosity on the fabrics. The ions in the henna, neem and turmeric will attract the coating ions and will form a larger molecules which can closed the pores between the cotton fibers. Another researcher explained there were low surface energy for the coated fabric samples and therefore more attraction of dye particles to the running liquid than to the solid surface itself [30]. Another reason was that the cellulosic fibers will combine with the dyes mainly by hydrogen bonding as well as Van der walls forces and do not have any identifiable dye sites. As a results there is usually no specific limit to the amount of dyes where the fibers will absorb the maximum dye molecules during the dyeing process and coating molecules [31]. Apart from that, the natural dyes have good dye attraction towards the fabrics due to the strong covalent bonds between the dye molecules and the fibre on the fabrics while there were some uncovered pores in the fabrics. Besides that, the cotton fabrics were absorbed more dyes and particles from superhydrophobic coating than other fabrics because cotton is made up from cellulose fibres [32]. The current study of porosity is using capacitance sensing approach for the frost growth on heat pumping [33]. 


\section{Conclusion}

The preparation of natural dyes based on neem, henna and turmeric were successfully obtained and was dye on the fabrics. The present research was studied to determine the abrasion strength and porosity for the uncoated and coated dyed cotton fabrics. The results of this research showed the decreasing of weight loss at $2.0 \mathrm{~g} / \mathrm{ml}$ for the coated henna was $3.32 \%$, neem at $3.33 \%$ and turmeric at $3.34 \%$ compared to the uncoated dyed cotton fabric. It reveals that the abrasion strength was good at $2.0 \mathrm{~g} / \mathrm{ml}$ compared to other concentrations. The porosity results were shown that $6.13 \%$ for the coated turmeric, henna at $6.31 \%$ and neem at $10.01 \%$ and it explained that the number of pores in the cotton fabrics decreases when the concentration of dyes increases with the superhydrophobic coating. The findings from this research make several contribution to the current literature. Further experiments and studies that involved natural dyes are strongly recommended. There are a lot of natural resources which have not discovered yet. Moreover more active researcher is needed to build a knowledge base and database with the production of appropriate studies for different textiles. It would be interesting to assess the effect of UV exposure on the uncoated and coated dyed cotton fabrics.

\section{Acknowledgement}

The authors would like to thank the Universiti Tun Hussein Onn Malaysia for supporting this project under Contract Grant by UTHM Scheme under Vot H339, Grant Contract H464, GPPS Grant H341 and Puspamara Sendirian Berhad.

\section{References}

[1] Kusumawati, N., Santoso, A. B., Sianita, M. M., \& Muslim, S. (2017). Extraction, Characterization and Application of Natural Dyes from the Fresh Mangosteen (Garcinia mangostana L.) Peel. International Journal on Advanced Science, Engineering and Information Technology, 7(3), 878-884.

[2] Ali, R. A. M., \& Nayan, N. (2010). Fabrication and analysis of dye-sensitized solar cell using natural dye extracted from dragon fruit. International Journal of Integrated Engineering, 2(3). 1-7

[3] Arora, J., Agarwal, P., \& Gupta, G. (2017). Rainbow of natural dyes on textiles using plants extracts: Sustainable and eco-friendly processes. Journal of Green and Sustainable Chemistry, 7(1), 35-47.

[4] Siddiqui, S. I., Fatima, B., Tara, N., Rathi, G., \& Chaudhry, S. A. (2019). Recent advances in remediation of synthetic dyes from wastewaters using sustainable and low-cost adsorbents.The impact and prospects of green chemistry for textile technology, 7(5), 471-507.

[5] Li, H. X., Xu, B., Tang, L., Zhang, J. H., \& Mao, Z. G. (2015). Reductive decolorization of indigo carmine dye with Bacillus sp. MZS10. International Journal of Biodeterioration \& Biodegradation, 103, 30-37.

[6] Yamjala, K., Nainar, M. S., \& Ramisetti, N. R. (2016). Methods for the analysis of azo dyes employed in food industry-a review. Journal of Food chemistry, 192, 813-824.

[7] Sharma, A., Kadam, S., Mathur, P., \& Sheikh, J. (2019). Re-using henna natural dyeing wastewater for coloration and multifunctional finishing of linen fabric. Journal of Sustainable Chemistry and Pharmacy, 11, $17-22$.

[8] Bhuiyan, M. R., Hossain, M. A., Zakaria, M., Islam, M. N., \& Uddin, M. Z. (2017). Chitosan coated cotton fiber: physical and antimicrobial properties for apparel use. Journal of Polymers and the Environment, 25(2), 334-342.

[9] Khazaeli, P., Mehrabani, M., Mosadegh, A., Bios, S., \& Moshafi, M. H. (2019). Identification of Luteolin in Henna (Lawsonia inermis) Oil, a Persion Medicine Product, by HPTLC and Evaluating Its Antimicrobial Effects. Research Journal of Pharmacognosy, 6(1), 51-55.

[10] Gupta, A., Mahajan, S., \& Sharma, R. (2015). Evaluation of antimicrobial activity of Curcuma longa rhizome extract against Staphylococcus aureus. Biotechnology reports, 6, 51-55.

[11] Ilangovan, M., Guna, V., Hu, C., Nagananda, G. S., \& Reddy, N. (2018). Curcuma longa L. plant residue as a source for natural cellulose fibers with antimicrobial activity. Journal of Industrial crops and products, 112 , 556-560.

[12] Adeel, S., Zia, K. M., Abdullah, M., Rehman, F. U., Salman, M., \& Zuber, M. (2019). Ultrasonic assisted improved extraction and dyeing of mordanted silk fabric using neem bark as source of natural colourant. Journal of Natural product research, 33(14), 2060-2072.

[13] Ganesan, P., Ramachandran, T., Karthik, T., Anand, V. P., \& Gowthaman, T. (2013). Process optimization of Aerva lanata extract treated textile material for microbial resistance in healthcare textiles. Journal of Fibers and polymers, 14(10), 1663-1673.

[14] Kumar, A., Pareek, P. K., Kadam, V. V., \& Shakyawar, D. B. (2016). Anti-moth efficacy of neem (Azadirachta indica A. Juss.) on woollen fabric. Indian Journal of Traditional Knowledge, 15(2), 272-277. 
[15] Chauhan, P., Kumar, A., \& Bhushan, B. (2019). Self-cleaning, stain-resistant and anti-bacterial superhydrophobic cotton fabric prepared by simple immersion technique. Journal of colloid and interface science, 535, 66-74.

[16] Taib, S. S., Ahmad, M. K., Nayan, N., Mohamad, F., Fong, S. C., Ameruddin, A. S., \& Bakar, F. A. (2018). TiO2 Based Dye-Sensitized Solar Cell Prepare by Using Spray Pyrolysis Deposition (SPD). International Journal of Integrated Engineering, 10(1). 78-84

[17] Sawant, S. E., \& Tajane, M. D. (2016). Formulation and evaluation of herbal ointment containing Neem and Turmeric extract. Journal of Scientific and Innovative Research, 5(4), 149-151.

[18] Udeani, N. A. (2015). Potential of henna leaves as dye and its fastness properties on fabric. World Academy of Science, Engineering and Technology International Journal of Chemical and Molecular Engineering, 9(12), 1459-1466.

[19] Marsi, N., Rus, A. Z. M., Mohd Razali, I., Samsuddin, S. A., Rashid, A., \& Hani, A. (2017). The Synthesis and Surface Properties of Newly Eco-Resin Based Coconut Oil for Superhydrophobic Coating. Journal of Solid State Phenomena, 266, 59-63

[20] Cakir, M., Kartal, I., \& Yildiz, Z. (2014). The preparation of UV-cured superhydrophobic cotton fabric surfaces by electrospinning method. Textile Research Journal, 84(14), 1528-1538.

[21] Matković, V. P., \& Skenderi, Z. (2015). Mechanical properties of polyurethane coated knitted fabrics. Fibres \& Textiles in Eastern Europe, 4(100), 86-91.

[22] Kanniappan, R. (2015). Assessment of dyeing properties and quality parameters of natural dye extracted from Lawsonia inermis. European Journal of Experimental Biology, 5(7), 62-70.

[23] Singh, D. K., Luqman, S., \& Mathur, A. K. (2015). Lawsonia inermis L.-A commercially important primaeval dying and medicinal plant with diverse pharmacological activity: A review. Journal of Industrial crops and products, 65, 269-286.

[24] Pasandi Pour, A., \& Farahbakhsh, H. (2019). Lawsonia inermis L. leaves aqueous extract as a natural antioxidant and antibacterial product. Journal of Natural product research, 6(2), 1-5.

[25] Riga, P., Benedicto, L., Gil-Izquierdo, Á., Collado-González, J., Ferreres, F., \& Medina, S. (2019). Diffuse light affects the contents of vitamin C, phenolic compounds and free amino acids in lettuce plants. Journal of Food chemistry, 272, 227-234.

[26] Thakur, B. K., Kumar, A., \& Kumar, D. (2019). Green synthesis of titanium dioxide nanoparticles using Azadirachta indica leaf extract and evaluation of their antibacterial activity. South African Journal of Botany, 124, 223-227.

[27] Marsi N, Rus AZ, Tan na. (2017). The Effects of Curcuma Longa on the Functionality of Pigmentation for Thin Film Coating. Journal of Materials Science and Engineering 226 (1), 121-126.

[28] Ma, X., Wei, Y., Wang, S., Zuo, X., \& Shen, B. (2019). Sustainable ultrasound-assisted ultralow liquor ratio dyeing of cotton fabric with natural turmeric dye. Textile Research Journal. 8(1), 7-14

[29] Wang, M., Zhang, Z., Li, Y., \& Men, X. (2019). Multifunctional superamphiphobic fabric with hierarchical structures via a mild water-based strategy. Applied Surface Science, 470, 687-694.

[30] Yang, Y., Huang, W., Guo, Z., Zhang, S., Wu, F., Huang, J., \& Gu, S. Robust fluorine-free colorful superhydrophobic PDMS/NH 2-MIL-125 (Ti)@ cotton fabrics for improved ultraviolet resistance and efficient oil-water separation. Journal of Cellulose, 7(6), 1-14.

[31] Khatri, A., Peerzada, M. H., Mohsin, M., \& White, M. (2015). A review on developments in dyeing cotton fabrics with reactive dyes for reducing effluent pollution. Journal of Cleaner Production, 87, 50-57.

[32] Udeani, N. A. (2015). Potential of henna leaves as dye and its fastness properties on fabric. World Academy of Science, Engineering and Technology International Journal of Chemical and Molecular Engineering, 9(12), 1459-1466.

[33] Selvam, R. M., Athinarayanan, G., Nanthini, A. U. R., Singh, A. R., Kalirajan, K., \& Selvakumar, P. M. (2015). Extraction of natural dyes from Curcuma longa, Trigonella foenum graecum and Nerium oleander, plants and their application in antimicrobial fabric. Industrial Crops and Products, 70, 84-90. 